\title{
Higher education and scientific research of third world countries need professional support: Case of Jordan
}

\author{
Abdul Aziz Farid Saymeh ${ }^{1}$, Harbi Ariqat ${ }^{2}$, Saeid Aqel $^{2}$ \\ ${ }^{1}$ Accounting and Finance Department, Middle East University, Amman, Jordan \\ ${ }^{2}$ Finance and Banking Department, Petra University, Amman, Jordan
}

Email address:

abdul_aziz48@hotmail.com (Abdul A. F.S.)

To cite this article:

Abdul Aziz Farid Saymeh, Harbi Ariqat, Saeid Aqel. Higher Education and Scientific Research of Third World Countries Need Professional Support: Case of Jordan. Education Journal. Vol. 3, No. 4, 2014, pp. 245-255. doi: 10.11648/j.edu.20140304.17

\begin{abstract}
Higher Education is the summit of the educational system, the culmination of the academic track, and eventually the end of the formal educational ladder for all students. It is the cornerstone of the knowledge development for the society. Institutions of higher education are the centers for policy and strategic directors for active and influential communities. This study aims to emphasize the importance of re- structuring of university education programs to enhance university curricula and keep pace with developments perceived by third world countries that cope with the global challenges for the era of globalization in the field of higher education and scientific institutions and give them the ability and efficiency to compete in the rehabilitation and development of graduates and researchers. This research is based on the written literature in this field, as well as relevant statistical analysis in order to get to a confined strategy for the development of the third world higher education in all stages, and is linked to the global developments as well. Researchers found that world developments and global changes being brought about by recent world technological and the modern means of telecommunications requires that developing countries have to strive and to develop their traditional university systems to cope with the new market demands. Third world higher education centers need to follow the modern university systems and modern application of educational technology, such as E-learning and distance education so as to produce university graduates who are qualified to work and compete with their rivals in the developed countries through acquiring the most modified skills and international experiences. The main aim of this study is to focus on the realities of third world higher education and research, and how to be able to face all the challenges and prospects of the twenty-first century in order to cope with the international developments and innovations. In this paper, researchers have concluded that the quality of university education and scientific research in developing countries are affected by many factors commensurate to commercialization, GDPs, B Ops, and population growth. Appropriate policies and academic development plans are deemly necessary for improving the quality of higher education.
\end{abstract}

Keywords: Higher Education, Scientific Research, Third World Countries, Internationalization, Globalization, Developing Countries

\section{Introduction}

\subsection{Overview}

Over the past decade, a new dynamism has emerged in all of the key areas of higher education, research and innovation in the field of higher education including:

A - demand, B - diversification rules, C - Change in learning needs, D - growth sectors of telecommunications, information technology, E - Strengthening and social networking posts. For these effects, it was evident that there is a need for changes in the dynamics of educational and economic levels for the community as a whole [1]. For many countries, higher education is perceived as an important form of investment in home capital development. Higher education institutions are charged with formation of human capital through teaching, building knowledge base through research and knowledge development, and dissemination and use of knowledge by interacting with the knowledge users. Higher education is becoming 
increasingly competitive in terms of students, staff and resources. Because of the increasing demand for access to it by the masses, it has shifted from being the service of the elite, to a service open to the masses[2]. University education is the preparatory phase and the exercise experience for skills to be gained in order to fit and compete in the labor market. University education and training get graduates to be closer to the requirements of companies and institutions, and where the technology business has become prevalent worldwide. Due to the world new developments such as the globalization phenomenon which calls for the removal of all barriers to the movement of capital, information, and technology for all countries without any obstacles. University education has gained global status of skills which have become common by most global markets. It worth to add that the principle of globalization suggests that survival is always stronger. Work skills rely no more on the basic knowledge of the work systems, but they require lot of skills and expertise and the acquisition of the latest technological experiences with continuous development.

The technological advances have led to the events of substantial changes in many professions and skills that make up the whole backbone of most nations' outputs, and where the doors of work became open to all nations alike, the jobs are no longer limited to the citizens of the country, but have expanded to include all world countries who are characterized to the skills required [3]. The function of scientific research remains a major source of knowledge and innovation at the national, the regional, and international levels. So far, over the past decade, most of the industrialized countries were forced to face the dual challenge and goal of providing access to wider areas of the post-secondary vocational and educational levels, as well as ensuring adequate investment in the field of high-level research. This requires proving a delicate balance which depends on wise policies and more diverse funding base. To pursue government reforms to build a world-wide class systems of higher education, which emphasizes Quality in both research and teaching[1] .The third world faces huge challenges in the current era in which it should face with advanced scientific thinking and be enlightened by working on the development and acquisition requirements of the latest technological advances that contributes to keep pace with scientific development so that the third world country individual shall be able to face the challenges posed by any challenging thoughts such as globalization, also to be influenced by the many aspects of cultural, educational, as well as patterns of thinking, in addition to the economic and social factors. as well, there are other factors with political nature have transcend national borders as the implications of globalization, scientific and technical advancements as well as cultural developments. There is a danger lies in the prospects of the social changes that may accompany this phenomenon, which includes the social aspects and values [4]. The nature of global labor markets including many multinational companies are mainly concerned with profitability and global spread, and so they do not follow their home country regulations; this means that they may be more loyal to the country which grants them more profits. These companies are therefore concerned with the products/services quality and cost which makes them attracted to the workforce with experience and are equipped with skills regardless of the nationality of individuals of their employees. It is vital to highlight the importance of college and university education, which requires sophisticated and modern university courses which are needed for the preparation strategy, planning and work to achieve preference skilled fields of study granulocytes and replace them with grades school achievement tests, intelligence and inclinations and aptitudes as they reflect reality and sincerity of areas where the student excels [5]. It has to be noted that the forms of public and private higher education institutions have changed dramatically over the past decade. Changes have resulted from both the emergence of private higher education markets and the growth of these markets through globalization[6]. Quality assurance should be viewed in the context of a country's public policies to provide educational opportunities for citizens. Issues of quality assurance have become a focus of attention in both developing and transitioning countries [7] .

\subsection{Assessment of Higher Education Learning Outcomes:}

Existing international comparisons and rankings of higher education institutions focus on research; to complement this, OECD inclines to develop a measure that would reflect a weighted evaluation to teaching and learning. A successful assessment will provide stakeholders of education institutions, governments, students and employers with better information on what the first university degree students know and can do. A motivation in this work is that this information could contribute to higher education institutions' knowledge of their own teaching performance, and thereby provide a tool for development and improvement. A feasibility test for assessment of higher education outcomes will allow comparison between higher education institutions across countries. This is done in the context of the massive growth in higher education, and increasing international attention to comparisons between institutions. The purpose of the test is to determine whether the international assessment is scientifically and practically based. The assessment will be done at the institutional level. It is expected that the assessment will be based on aptitude and proficiency written tests intended to measure the competences of students who are almost at the end of the first university degree program (Bachelor program). Experts advise that this feasibility test should look into the transverse of critical thinking and problem solving skills which are necessary for the success of university graduates in academic and business contexts. This test should be combined with a subjective test related to the most basic disciplines. It is important that the assessment test should be of high validity 
as it is to be conducted across a variety of institutions, cultures, and disciplines at which the test presents numerous scientific and practical challenges. Amongst these, the test has to consider the following points:

The diversity of institutions; differences between national systems of higher education; variations in the duration and content of programs; cultural and linguistic diversity; and accounting for the institutions' added values [8].

\subsection{Fear and Hope}

A powerful element of public interest in higher education is the added value in getting well developed systems for research and knowledge generation. It is so vital for emerging knowledge economies that they give the concerned country the opportunity to generate updated knowledge as well as being engaged into the scholastic and scientific deals with other countries. Scientific research and knowledge usually flourish when new findings are widely shared by societies and within open forum. It is worth to mention that public support of scientific development and knowledge generation is so essential in third world countries. Research universities usually integrate their practices with added values and are conductive to knowledge generation such as ideological neutrality in research topic selections. Links occur between scientific research and university education as both are integrated institutions. It is worth to add that not all knowledge types can be internally produced as worldwide knowledge systems provide benefits associated with specialization and exchange. International scientific involvement helps most of developing countries to be wide and open to broader economic, intellectual, and technical systems. All nations are urged to remove all legal restrictions on the flow of researches and new ideas. It is deem difficult for any country to invest alone in any transnational problems, simply because others will benefit without paying any effort or contribution. So an international network of research centers or universities is becoming a must so as to insure advancement in the required research agenda. International knowledge exchange requires that every country is required to meet the international standards in this respect. So improving university education is becoming a common denominator for all countries [9]. In general, third world students have a purpose of attaining higher education, they view it as a vital step to creating new generations of elite graduates that will understand and solve problems in their developing societies, and are eager to transform them from being historically ignorant and of perpetual poverty into educated and well doing societies. At the individual country level, educators view higher education as a means of getting knowledge, skills and qualifications that will enable low leveled society graduates to get more recognized jobs that will transform their families from the majority of being peasants or primitive laborers with low income levels to better family ranks with higher economical levels. However, many humanity section graduates feel that higher education has little value for the money paid because of a number of factors:

--There are too many graduates which results in unemployment even of those who excel and do "good" courses.

--Graduates think that the content and teaching approaches are too theoretical, resulting in becoming job seekers and not job makers.

However, engineers, teachers and other vocational graduates have the hope of competing quite favorably on the job market or being more self employed.

\section{Literature Back Ground}

\subsection{Higher Education, Research and Innovation}

The function of scientific research is still a major source of knowledge and innovation at the national, regional and international levels; over the past decades, more industrialized countries have had to face the dual challenge of providing access to education and training of university education and ensure adequate investment in research at sustainable high-levels. This would depend on the wise policies and the vision of governments for the future and to provide more diversified funding bases. The follow-ups of educational reforms adopted by governments to build world-class systems of higher education have led to quality assurance in both research and teaching. For universities that works to keep education and research at senior and advanced levels have to work on the continued growth of their curricula and researches. OECD statistics showed that twenty-two of the top twenty-five university research centers are located in the U.S.A.. Although that higher education in U.S.A. deserves the full praise for the breadth and the provision of resources to the sector of education and research, yet it cannot be enough to meet the global needs $t$ in the research. For this it is necessary to provide support to all universities, research interest, especially those at the forefront of the fields of science, technology and innovation, these university centers have become important members of priority in OECD countries [10].

\subsection{Policy Dynamics in Higher Education and Research}

Governance and management definitions in higher education are based on analysis levels, Clark classified higher education into three levels:

1- Basic academic or disciplinary units;

2- The middle or individual organizations..

3- The vast array of government and other systems.

Regulatory mechanisms that relate organ izations to one another differ according to context. The context depends on where higher education institutions are located within a triangular field of governance/coordination constituted by academic authority, state authority and the market. We find these three "ideal types" of coordination in developing and developed countries alike [11]. 


\subsection{Internationalization and Globalization of Higher Education and Research}

In some of the functions of orientations, universities and research centers used international approach, great efforts were made to get the most advanced stages of knowledge throughout the world. The identification of more knowledge is a duty relied on all scientific and research centers all over the world to participate in the global knowledge base by contributing in many areas of international scientific research. Internationalization often points to the growth of knowledge across border activities among nations, while globalization often implies the free move of wealth, goods, and knowledge among the borders and nations. Moreover, specific issues tend to be linked to the individual terms [12]. Changes to higher education governance have evolved in many jurisdictions of the state from direct control of higher education to a state supervisory model. Many governments have moved towards the market forces of higher education institutions hoping that this will enhance the efficiency and accountability of university education, and simultaneously reducing the financial burden of higher education on the public interest. Ordorika explains that globalization has substantially modified the nature of contemporary NationStates as the principal organizers of capital bearers and as burden and creators of national identities, he added : 'due to globalization and internationalization processes as well as changes in the nature of Nation-States, initiatives for accountability have been promoted in almost every area of societal life'. The emergence of a higher education market poses a significant challenge for national research universities, however, universities and regardless of their belongings are in need to participate in the global realm of colleges and universities on the basis of their own academic nature and distinctive character. For this objective, it is very much important to understand the implied nature of concepts and notions of research outcomes and the output which are deeply related to market oriented institutions of university education [13]. Reforming higher education systems was the initial step in adopting globalization in higher education. European and American governments were not able to fund the increased cost of their higher institutions due to the increase in enrolments and the demand for higher training. This financial challenge was adjusted and solved by reforming the education systems to permit the private sector to invest in university education, and by increasing tuition fees. It can be debatable that the idea of raising tuition fees may be rejected by many academic stakeholders while private investments in higher education may create new academic initiatives and will cause a real improve and thus enhance competitiveness in the international university education quality [14]. Competition in international higher education market encourages innovation and research development. Many studies have confirmed that research policies were reformed to enhance the competitiveness of higher education [15]. The international higher education market has become a fact and cannot be ignored. Meny confirmed that higher education centers can pursue international higher education markets if they are able to succeed in competing and are able to enter into the education market [16]. DeWit also believes that Globalization of higher education will affect the universities' culture and curricula, it will also enhance the reputation of home universities. He also adds that globalization of higher education will upgrade the university's brand name and encourage most universities to transact more international agreements [17]. Higher education programs in many developed countries has made them exporters of higher education to developing countries. Indeed, there are mutual benefits between developed and developing countries, they benefit from each other as developed countries need more sources of income, and developing countries are in need for new knowledge, technology, and education [18]. Olaniran and Agnello argue that education systems in the developing countries have struggled to interact with technologies to train their workers. They argue that local education was not adequate to cope with the needs of international labor markets and believe that international higher education a vital issue for their success [19].

\subsection{Global Challenges to Higher Education Quality and Quality Assurance}

It is worth to consider some passive outcomes of Globalization of Higher Education and Research in that it has a damaging consequence:

1. It may lead to poor and unregulated quality of higher education attached to a worldwide marketing of fraudulent degrees of higher education credentials. Franchised universities are becoming problematic as the home country university offers lower and substandard education through its franchised programs in other countries. Most of such universities are motivated by the financial gain but not by spreading academic excellence to developing countries.

2. Demographic dynamics will be partly created by and articulated through globalization. This will affect the ability of most countries to meet Higher Education access and capacity challenges.

3. It may create shifting patterns of production and consumption responding to irregular employment alignment issues.

4. It may act as a stimulus and embodiment of knowledge dynamics. It may create a supernatural information that will erode the traditional sources of knowledge and standards.

5. Income inequalities combined with the ideology of new liberalism and private sector realization will deny education as a public good, and switch education as a commodity available only to those who can afford for it [20]. 2.5 The Role of Universities in Higher Education and Research Systems 
The basic role of the university in the national development system or economy has become relatively controversial. Most academics' agree on the role of the university in disseminating knowledge through teaching and related activities, however, there might be certain disagreements regarding its role in generating knowledge, and even less agreement on its linkage to the industry and the commercial market. Nonetheless, most advanced and industrialized countries are all highly aggressively concerned to maintain and enhance strong research and innovation systems [21]. Research capacity is also important for low-and middle-income countries for the sake of promoting their economies. It is also required for effective management, development of sound policies in the governments and civil societies, as well as maintaining the national histories, cultures and identities. The R \& D in the OECD countries does not depend on universities. That's where about 80 per cent of research and development projects in these countries are carried out by business and industry. Also, researchers noticed that the major percentage of research and development projects have not been done in universities and research centers. However, research and development projects have grown dramatically in the past few decades and the majority of them were funded by both governments and the private sectors. It is worth to note that most of these countries lack the presence of a strong private sector and thus the funding has been done through their governments [22].

\subsection{Quality and Relevance in Higher Education and Research}

Efforts have exerted by UNESCO, Forum for Higher Education, Research and Knowledge, have formulated what constituted excellent teaching and research universities share the following "characteristics":

-High-quality faculty committed to research and teaching.

-High-quality graduate students, who want to learn to perform research or function with advanced expertise.

-An intellectual climate that encourages scholarship.

-Facilities in which teaching and research can be performed effectively.

-Funding for operations and instruction.

-Research funding.

-Research infrastructure.

-High-quality leadership [23].

Over the past four decades, many educators have noted divergences as per the management of universities is concerned. Of the characteristics quoted above, some put emphasis on university management while others call for strong academic self-governance.

Over these years, the implementation of the teaching and learning quality in economically advanced countries, and to the majority of low- and middle-income countries was strongly shaped by the notion of "massification" of higher education. In the process, quality increasingly has been viewed as endangered:

- By increasing the proportion of students prepared for and motivated by quality of education, against a declining willingness of governments to keep average expenditures per student on an adequate level.

- By increasing provision of private higher education, inclined in some cases to provide, or sell, higher education on a low-quality level.

Private higher education usually intends to offer higher education provisions closely linked to the needs of the market needs : concentration is always done in the fields of high demands, curricula were oriented to presumed job description and needs, concentrating upon teaching by practitioners and relevant careers, more practical experience during the course of study, more active help in the job search processed. But alas, various experts commented that often the study provisions at private institutions of higher education are very low in quality. In some cases, the quality might be so low that graduates of these institutions do not find any job opportunities in the targeted areas. It is worth to elaborate that in regard to "profit-seeking, higher education institutions" in some developing countries most university teachers were not adequately qualified and they lack job security, and as for students, too many of them come to universities with low education levels and with attitudes that concentrate towards getting a university degree. In addition, Most students who go to private, profit-seeking higher education institutions in order to get a degree in certain disciplines are unable to exercise their respective professions when they end their university study. A very important reason for this failure is the bad quality of studies in most developing countries [24].

\subsection{Online E. Learning}

Online e-learning occurs entirely without any face-to face interaction. Course outlines and other materials are transferred electronically through email, websites, online forums, or via CDs, DVD-or ROMs.

Combined learning uses a combination of Internetdirected instruction, as well as face-to-face interaction. Most traditional colleges and universities use combined learning as students learn in physical classrooms, with instruction augmented by online lessons.

Higher education represents the summit of the educational system and the culmination of the path the school and ultimately the top of the education levels of students. As of this pioneering role played by associations and other educational institutions associated with changes in their goals, systems, and forms. Challenges on the success of any educational system depends on the commitment of this system to the international standards for quality of $\mathrm{E}$. learning due to the remote distance between students and education resources. Online learning has made a major impact in the world of education. Recent studies show that online learning is an effective and reputable way to earn a college degree. According to a survey from the Department of Education conducted in 2009 showed that students who took all or 
part of their class online performed on average better than those taking the same course through traditional face-toface instruction. Also study showed that Students who combined online learning with the traditional coursework did better [25].

\section{Experiences of Successful Countries}

\subsection{South Korean Higher Education}

To meet the demands of globalization, Korean universities have redesigned and started implementing internationalization policies that basically rely on globalization principles. South Korean Officials have realized that higher education power is embedded within the internationalization standards. They have accepted the notion that the U.S.A. is the world's superpower and therefore Korea is urged to compel to "Westernize" its higher education in order to be an active participants in the highly competitive globalized era and this has to affect the perspectives of Koreans issues pertaining higher education including all concerned including professors, students, government officials, and university administrators. The theoretical framework, theories of neo-institutionalism and resource dependency theories combined were adopted to explain why universities decide for a specific set of internationalization instruments. A set of internal and external pressures can influence this decision, and this is due to their distinct dependencies and attitudes towards internationalization, it was expected that there are differences in the reasons for internationalization and the use of internationalization strategies among private/public and regional/metropolitan universities [25]. From the perspective that U.S.A. is in control of the world and it acts as the globalization pioneer and leader, other nations, however, were urged, obliged, or aim to assimilate the American culture such as implementing the English language as the powerful form of international communication. For this other semi-peripheral and peripheral countries have attempted to gain access to the U.S.A. in surrendering aspects of their cultural values in favor of developing positive relations that will help them develop their characteristics, agendas, and global stage. It is worth to add that the main goal of the Korea Universities is about educating their students in a way to make them able to survive in the global competitive environment by sending their own students abroad and attract high quality students and scholars from other prestigious higher education institutions to maintain their high level of university education prestige. The internationalization process has positively affected Korean higher education, the attitudes in which the government and higher education institutions responded and so internationalization already become an integral part of mainstream of Korea's higher education policies and programs and is increasingly perceived as an effective tool to improving the quality of higher education [26].

\subsection{Japan's University Internationalization and its Assessment}

Under the circumstances of globalization and internationalization, Japanese higher education has been highly appreciated. Excellent and diverse education and research activities have been promoted under the wellbalanced coordination with the establishment approval system and the quality assurance and accreditation system, which is continually reviewed for more efficient system. In Japan, academic freedom has been respected, as the Constitution of Japan stipulates that every citizen shall be entitled to equal opportunities to receive education in accordance with concerned laws and according to his or her ability. Also, it should be emphasized that the Fundamental Law of Education stipulates that the independence, autonomy and the merits of education and research by higher education institutions shall be respected. This principle of self-governance has been assured by Japanese Supreme Court decision. Internationalization of higher education has been an indicator of quality development in higher education and at the same time there is more debate about the added value and quality of internationalization itself [27]. Internationalization of higher education has become an instrument of competition, branding, and profiling as supporting institutional goals that are meaningful to a variety of stakeholders. In terms of internationalization, a collaborative benchmarking exercise among universities across national boundaries would be effective for those highly motivated institutions. However, An institution that seeks to be comprehensively internationalized, infusing internationalization throughout its many programs and making it a way of accomplishing its central work, must also pay attention to what students are leaning, technology advancements Market needs, etc. As for the internationalization of university education, Higher Education Institutions need to shift from the "addon" approach to the "transformation" and creative approach with priority and concentration on hands on principles. The newly added so-called international programs have hardly brought about the major transformation of the whole university objectives [28].

\subsection{Higher Education in European Union}

In the European Union, higher education is the responsibility of Member States, also it is worth to indicate that European Union institutions play a real supporting role. Article no. 165 of the the European Union function states that the European Community is urged to contribute to the higher education quality development that can be achieved by reinforcing the inter member states cooperation through promoting the movement of European Citizens, designing joint higher education programs, and exchanging information and teaching languages. E.U. higher education treaty confirms the commitment of its members to promote the learning process for the union citizens. EU agencies fund educational, vocational and citizenship-building 
programs which encouraged EU citizens to take advantage of such educational opportunities offered by the EU educational agencies to study and work in other E.U. countries. Since 2000, EU Member States have begun working together to achieve a set of 13 specific goals in the field of Education [29]. In the Bologna declaration of 1999, European ministers have initiated the Bologna Process by setting out the goal of establishing the European Higher Education Area (EHEA) to start operation by 2010. Also, ministers, expressed the need to dialogue with the wider world regarding the EHEA, and explore the role of the EHEA in a broader global perspective. Ministers also founded the European University Association (EUA) acted as the voice of European Universities. Through its work, EUA sought to ensure that universities' interests are taken into account in all relevant policy areas, by providing input and advice on their behalf regarding the development and revision of a range of European policies, programs and funding instruments. Directorate General for Education and Culture of the European Commission has contracted with the independent educational agency: The Bologna Agency to assess the extent to which the operational objectives of the Bologna Declaration of 1999 and subsequent communiqués have been achieved in the areas of curriculum reform, quality assurance, qualification, frameworks, recognition, mobility and social equity. It also evaluated the extent to which the operational objectives have led to the achievement of the strategic objectives of the Bologna Declaration. Overall, higher education across the 46 EHEA countries looked substantially different from 10 years ago. Most of the 46 countries have adopted new higher education legislation to introduce and regulate elements of the Bologna Process. Many countries have allocated additional funds for the implementation of new Bologna policies. The European Commission has also supported projects for the introduction of reforms. The Cooperation between the higher education institutions from European Union countries and counterparts abroad in Africa, Latin America has increased. The Bologna Process has become a major focus of attention for regional and sometimes also national higher education policy-making around the world such as China and U.S.A. [30].

\subsection{Higher Education in U.S. A.}

In the $20^{\text {th }}$ century the United States was "the most powerful nation since Imperial Rome", dominating the world economy, culture, political, and military. Also, the United States still remains a military superpower and enjoys the world's largest economy. It is worth to indicate that the rapid economic growth and expansion happening in other countries show that a country's global position cannot be taken for granted. The world is witnessing a great transformation in many directions, and it is taking place in education, as well. In the second half of the 20th century, the United States was indeed the world leader in education. It was the first country to achieve mass secondary education, while European countries were stuck to their elite classical higher education systems, the United States has dramatically expanded higher education opportunities for its nationals and the result that it has had the largest supply of highly qualified people in the adult labor force more than any country in the world. This tremendous stock of highly educated human capital has helped the United States to become the dominant economy in the world and to take advantage of the globalization and expansion of markets. At the higher education level, the United States has a strong system that has been admired around the world and has become the world's leader in research [31]. According to the 2010 records of Higher Education World University rankings, 18 of the top 20 universities in the world were in America. Also the United States is among the world leaders in the proportion aging between 35- to 64years with college degrees. By 1995, the United States was tied to be the first in university and college graduation rates. However, as the importance of the highly educated workforce in the global economy was becoming ever clearer, other countries began to dramatically expand their higher education systems similar to what the United States had done in the earlier decades. Due to this higher education improvement, the United States has retreated back to be ranked the 15th among the world top 29 countries with comparable data in 2008. Overall, the United States has lost ground in such international comparisons as the pace of higher education expansion has accelerated around the globe. However, the older generations of U.S. Americans were better educated than their international peers as many other countries have a higher proportion of younger workers with completed college degrees [32]. This development of international educated talents around the globe reveals that the United States will not have the most educated workforce in the world as it has had in the past [33].

\section{Higher Education in Developing Countries}

Higher education, and particularly university education in developing countries is recognized as a key force for modernization and development. This has caused an increase in the demand for its access, and is accompanied by a number of challenges. Higher education is considered as a vital form of investment in the national capital development. Higher education institutions are concerned with the formation of human capital through teaching, building knowledge bases, innovating through research and development, and dissemination by interacting with the knowledge users. For most developing countries, higher education has become highly competitive in terms of students, staff, and resources. Due to the increasing demand for access to it by huge numbers, it has shifted from being the elite path, to an open service to the common [2]. In developing countries, the quality of higher education is affected mostly by the 4 Cs forces: i) The changing 
university customs characteristics, ii) Increasing competition, iii) Rising costs, and iv) The impending crises. To understand these forces, institutions of higher education need to aggressively improve and strengthen themselves, otherwise, they cease to be the academic centers excellence [34]. In developing countries, higher education institutions are either private or mostly public. Private institutions generate money from fees and external aid, while public institutions get government grants as well as generating funds from fees and donors. As the demand for higher education is increasing, educational entrepreneurs and managers are thus challenged in taking investment decisions by which they can achieve desired financial goals without setting fees structures that are so intolerable as to scare away potential customers [35]. Due to the commercialization of higher education, courses have been fragmented leading to very early specialization yet students get attracted to courses by name and not content. Kasozi confirms that the majority of the some 1800 or more programs offered at universities and other higher institutions are mostly theoretical and irrelevant to the market needs [36].

In his book, "Scholars in the Marketplace", Madani accused universities of duplicating courses for the sake of generating revenue from private students. Initiatives to ensure quality in private higher education institutions began in the early 90s after the collapse of the Soviet Union. Higher education has increasingly become expensive in terms of tuition, resulting in high rates of attrition students who drop out half way [37]. Expensive accommodation, food and transportation have compelled the students' majority to reside in slums or sheds that are close to their institutions, most often, going without meals which causes some to faint especially during examinations. The fees of higher education remains the major obstacle of the university sector. Most universities get less than $30 \%$ of courses costs for student per year and fail to get the $70 \%$. This causes a cut down on education facilities, quality of staff as well as building and repair of infrastructure [37].

.National Commission for Health Education Credentialing (NCHE) data showed that the fees paid by the privately sponsored students and the grants from the government-sponsored students is $29 \%$ of what would be the actual cost and this has an effect on the quality of higher education. It is worth to conclude that the quality of university education in developing countries is mainly influenced by many complex commercialization, general funding, and human population growth. An important concern facing developing countries is how to ensure quality for a wider and more diverse set of higher educational institutions. Quality control processes such as accreditation, accountability and assessment have unique relevance as higher education faces dramatic changes in developing countries due to the world becoming more globalized and internationalized, and as private higher education institutions are increasing in number and students enroll is increasing.
However more realistic and appropriate policies of both academic and administrative are of deem necessity for improving the quality of university education in developing countries [38].

\subsection{Should Low-Income Countries Invest in Research}

All Countries Need to Use Research Findings: The need for investments dedicated to building a proper basis for higher education, research and innovation (HERI). Until recently, this issue has not been widely recognized by most governments of low-income countries. Some argue that relevant research may be better done internationally, and that low-income countries should rely on research findings produced elsewhere rather than invest in local research. All countries need to capitalize on the results of international research, low-income countries and due to the weaknesses of their national research that have all angling opportunities for taking advantage of new knowledge. An example to this point, in many developing countries, children still die from diseases that could easily be avoided and cured through the use of knowledge available internationally. Advantages sought from local research institutions go far beyond direct research work, and a research community can facilitate access to informed advice. Decision-makers seldom turn to research publications to find out about new resistance to life-saving medicines, they usually seek for advice from their local scientists, who know the literature and can consult international colleagues upon needs [39].

\section{Higher Education in Jordan}

Higher education in Jordan commenced by the establishment of Teachers House 'Dar Al-Mu'lemeen' in 1958. University education was commenced by the establishment of the University of Jordan in 1962, followed by the establishment of Al-Ahliyya Amman University in 1989 as the first private university in Jordan. During the last 20 years, university education in Jordan has gained prominent developments evidenced by the increasing number of higher education institutions, volume of enrolled students, the numbers of faculty members as well as administrative and academic research members. The number of public universities has reached (10), this is in addition to the World Islamic Sciences and Education University, while private universities are(17) in addition to (51) community colleges,. This increase in university number has been accompanied by significant increases in the number of enrolled students in both public and private universities which reached about (236) thousand; out of which (28) thousand are from Arab and foreign nationalities. The ministry of higher education has paid a special attention to higher education. Attention, herein, has been mostly focused on monitoring, evaluating, and modifying higher education programs and scientific research processes via a development plan for the years (2007-2012) [40]. 


\subsection{Quality of Higher Education in Jordan}

Quality of education refers to the standards of educational inputs, processes, and outputs set forth by an educational system. It is composed of many concepts that cover all the educational functions and activities. It is always envisioned as an objective that can be reached via all the processes of the reform [41]. Quality principle cannot be separated from excellence. However, it is judged primarily by the strength of the ethical and pedagogical principles it embodies [42]. In Jordan, no new institutions, public or private, should be created unless they can offer high standard of quality. The process of accrediting is conducted by the Accreditation Commission that mostly does not take into account the conceptual framework of the particular college or university to ensure that the candidates are prepared as defined by the institution's conceptual framework. Also, it worth to note that without the quality of higher education, Jordan cannot assure any genuine and sustainable development. For this, a powerful shake up is deeply needed to improve and assure quality is of deem necessity. University and College standards have to be set up, indicators have to be made clear, and quality assurance system should be reinforced. The search for quality is indispensable for a policy based on merit. In brief, the picture of higher education is not as glorious as it may seem. It needs modification so as to change the picture dramatically from one based on phony reputation to one based on real performance. Many attempts for reforms and modifications have done little but restate the obvious and recycle the devious. The ministry of higher education in Jordan intentionally avoids conducting performance reviews of its university and college programs. And without those reviews, higher education loses its accountability for all programs. A survey should be conducted to measure how much students learned and a rank for Jordan's universities based on their performance in educating students [43]. In terms of higher education relevance to market needs, higher education institutions have failed to cope with ever growing and emerging changes and evolution of the labor market. University students were not well equipped to participate in the rapidly evolving internationalized and globalized market. Jordanian employers do expect better outcomes and continually look for products which are tailored to their needs. This urges the ministry of higher education experts as well as universities to go out to the work field and orient themselves to the newer realities for the sake of working out solutions for the real needs of the society. Universities and community colleges in Jordan have done almost nothing to serve Jordan's community such as eliminating poverty, illiteracy, violence, hunger, nepotism, narrow mindedness, and disease [44].

Jordanian students are admitted to the universities on the basis of their grades in the General Secondary School Certificate Examination or its equivalent. However, there are certain sectors that have a different track to be accepted at the public universities known as the quotas for their advantage. Such quotas include the sons and daughters of the armed forces personnel. Other quotas are given to the sons and daughters of the school teachers, the public universities personnel, the tribes, and the Palestinian refugees. Other exceptions are given to the less privileged areas to be admitted to public universities regardless of their relatively lower grades in the General Secondary Examination. It is worth to note that this university acceptance formula is against the human rights law. Consequently, there is inability of public universities to attract bright minds which undermines the ability of the higher education institutions to produce well-qualified graduates[43]. Management of universities and colleges is heavily centralized. Jordan's Higher Education Council has an extreme power over private universities such as the appointment of presidents as well as deans. It should be stressed that autonomy of the universities must be respected and fostered, and be accompanied by a high level of responsibility and accountability [45].

Most of Jordan's universities adopt the traditional education approach which is based on memorization of books without enabling students to be inductive and innovative. Students were not given the opportunity of taking a critical or analytical approaches towards numerous subjects, and this is because faculty members were not trained in integrating technology into pedagogy, and discipline. As most faculty members are very poorly trained in teaching and have no preparation for teaching at all. They teach the way they were traditionally taught [46]. All public universities receive financial aid from the government. This creates financial burden on the shoulders of the government. Financing higher education must be considered as a form of investment, the return of this investment is being as much important as investment in all other sectors. It is worth to add that the real issue is not how much education costs, but how much it is worth. Although financing universities should be related to the university ratings, world class research activities, community service, quality of teaching, and number of students [However, in Jordan all universities are treated no differently from those universities that do nothing in these areas [47].

\section{Recommendations}

Following are the Main recommendations and justifications for the use of cutting-edge scientific methods to develop higher education and scientific research in Jordan:

1. Fill the diminishing capacity of universities to keep up with the steady increase in the number of high school graduates.

2. Cancel the special track university acceptances and the parallel programs.

3. All high school students should sit for aptitude and relevant proficiency tests and compete for enrollment 
on the basis of their achievement in these tests.

4. Keep pace with the constant evolution of university courses for the twenty first century and to cope with the scientific research development to achieve the requirements of this modern era.

5. Create academic institutional autonomy and mitigate government constraints and overruling.

6. Reinforce the hands on proficiency of university graduates that would save any extra training programs

7. Develop college and university required vocational training courses to fill the vocational vacancies in the labor market.

8. Work to unlock the potential of the individual and encourage innovation by providing the right climate for researchers and provide incentives to create and encourage individual and collective initiatives.

9. Urge the government to raise the scientific research budget and encourage and offer reasonable incentives to the public and private institutions to support and finance selective scientific research programs.

10. Recommend that the Ministry of Higher Education establish a curriculum development department that would act as a link between market and universities to cope with the ever growing needs for updated university curricula.

11. Universities must adopt appropriate strategies for the recruitment and training of the teaching personnel.

12. Widen the capabilities of higher education students via analytical skills, team work activities and innovative skills in order to enhance the quality of higher education.

13. Introduce an academic system whereby university presidents, deans, and chairmen are appointed through independent academic committees and based on academic proficiency and scientific contribution.

14. Universities should not have to focus on widening access to higher education by increasing student numbers but should ensure that the quality of higher education improves.

15. Government should increase funding for university education and research so as to spur economic development.

\section{References}

[1] Kearny M, "Higher Education, Research and Innovation: Charting the Course of the Changing Dynamics of the Knowledge Society", UNESCO Forum Mandate, 2009.

[2] Okwakol, "The Need for Transformative Strategic Planning in Universities in Uganda" NCHE Journal Kampala. 2009.

[3] Sarah Bunoti, "The Quality of Higher Education in Developing Countries Needs Professional Support", Lecturer, Department of Psychology, and Member of the Proficiency in General Education Committee, Kyambogo University, Kampala, Uganda, 2007,

[4] Nassar, S., "Educational issues in the era of globalization and postmodernism", Egyptian- Lebanese house, Cairo, 2005.

[5] Okwakol, "The Need for Transformative Strategic Planning in Universities in Uganda". NCHE Journal Kampala, 2009.

[6] OECD, "OECD Handbook for Internationally Comparative Education Statistics: Concepts, Standards, Definitions and Classifications", OECD Publishing, Paris, 2004.

[7] Labi, A., "International Assessment Effort Raises Concerns Among education Groups", Chronicle of Higher Education,, Washington, DC., Issue 28 September 2007

[8] OECD, "OECD Handbook for Internationally Comparative Education Statistics: Concepts, Standards, Definitions and Classifications", OECD Publishing, Paris, 2004,

[9] OECD, “THE TASK FORCEO ON HIGHERE DUCATION AND SOCIETY”,2000.

[10] Tokai, K., "Chair's Summary of the Informal OECD Ministerial Meeting on Evaluating the Outcomes of Higher Education", presented at the OECD Ministerial Meeting, Tokyo, 11-12 January 2008.

[11] Clark, S "The Higher Education System: Academic Organization in Cross-national Perspective". Berkeley: University of California Press, 1983.

[12] Teichler, U., "The changing debate on internationalization of higher education". Higher Education, Vol. 48, No. 1, pp. 5-26. 2004

[13] Ordorika, I., "Commitment to Society: Contemporary Challenges for Public Research Universities “, Paper presented at the Second Colloquium on Research and Higher Education, 2006

[14] Qiang, Z., Internationalization of Higher Education: towards a conceptual framework. Policy Futures in Education, 1(2), pp. $248-270,2003$.

[15] Article, "U.S. Higher Education", National Center for Public Policy and Higher Education",U.S.A. 2008.

[16] Mény, Y., "Higher education in Europe: National systems, European programmes, global issues. Can they be reconciled?", European Political Science, 7(3), 324-334. doi: 10.1057/eps, 2008.

[17] de Wit, H., "Globalization and internationalization of higher education", RUSC: Revista De Universidad Y Sociedad Del Conocimiento, 8(2), 241-248, 2011.

[18] Beerkens, E., "Globalization and higher education research. Journal of Studies in International Education”, 7(2), 128148. doi: 10.1177/1028315303007002002,, 2003.

[19] Olaniran, B. A., \& Agnello, M. F. "Globalization, educational hegemony, and higher education", Multicultural Education \& Technology Journal, 2(2), 68-86,, 2008.

[20] Neubauer, D, "Ten Globalization Challenges to Higher Education Quality and Quality Assurance", EWC, www.eastwestcenter.org, 2012.

[21] Xue, "Universities in China's National Innovation System", Paper presented at the Second Colloquium on Research and Higher Education Policy Universities as Centers of Research, 2006. 
[22] European Science Foundation (ESF), " Project on: Higher Education Looking Forward: An Agenda for Future Research", Synthesis Report of the ESF. www.esf.org., 2008.

[23] Brennan, J.; Enders, J.; Valimaa, J.; Musselin, C. and Teichler, U., "Higher Education Looking Forward: An Agenda for Future Research “, Strasbourg: European Science Foundation, 2008.

[24] CODESRIA. "Bulletin Nos. 3 and 4", Council for the Development of Social Science Research in Africa (CODESRIA), 2005.

[25] Littlefield, J, Mergner.J, "Online Learning Statistics, About Internationalization Strategies in South Korean Higher Education, UNIVERSITY OTWENTE - SCHOOL OF MANAGEMENT AND GOVERNANCE, 2013

[26] Byun, K., \& Kim, M., "Shifting patterns of the government's policies for the internationalization of Korean higher education", Journal of Studies in International Education, pp. 1-20, 2010.

[27] de Wit, H.," Measuring success in the internationalization of higher education", Amsterdam: European Association for International Education, 2009.

[28] Knight, J. "Internationalization remodeled: Definition, approaches, and rationales, Journal of Studies in International Education, Vol. 8, No. 1, pp. 5-31, 2004.

[29] Wikipedia, "the free encyclopedia", 2014,

[30] Cheps, "The first decade of working on the European Higher Education Area", International Center for Higher Education Research, KASSEL, 2008.

[31] Lee, J. J., \& Rice, C., "Welcome to America? International student perceptions of Discrimination". Higher Education, Vol. 53, No. 3, pp. 381-409, 2007.

[32] National Research Council, "Improving Measurement of Productivity in Higher Education", The National Academies Press, Washington,www.nap.edu/catalog.php?record_id=134 17,2012

[33] Swail, W.S., "In Search of a Better Mousetrap: A Look at Higher Education Ranking Systems", College and University, Vol. 86(4), AACRAO, Washington, DC., pp. 2833, 2011.

[34] Mpaata A. K., "University Competiveness through Quality assurance; The Challenging Battle for Intellectuals", 2010.
[35] Kayongo P. M.,"E-learning Services vs. Physical Education Institutions; which way to go in financial terms?", NCHE, Kampala, 2010

[36] Kasozi A.B.K.," The State of Higher Education 2005: Executive summary", NCHE, 2006b

[37] Madani M., "Scholars in the Marketplace. CODESRIA, Senegal, 2007

[38] Kasozi A.B.K.," Regulating Transnational Higher Education in Uganda; consumers should be cautious", NCHE, Kampala, 2006a

[39] Olsson, B and Mkandawire, T., "Compelling Rationale for Assessment Tools and Indicators for University Internationalization", Panel Discussion at Tokyo International Exchange Center, 2006.

[40] "Higher Education Report", Ministry of Higher Education and Scientific Research, Amman -Jordan, 2014.

[41] Jakson, Norman, "Growing Knowledge about QAA subject benchmarking, Quality Assurance in Education", Vol 10Number 3, pp. 139-154, ISSN 0968-4883, 2002.

[42] Burke,D \& Alwaked, A., "On the Threshold: Private Universities in Jordan", 1998, www.bc.edu.

[43] Khader, F, "Strategies and Roadmap for Effective Higher Education in Jordan" https://www.uop.edu.jo/download/Research/.../111_1548_kh ad.pdf, 2010.

[44] Jongsma, Ard "Jordan: Soaring Environments Create Problems. and Knowledge Creation: An Endangered Species?" UNESCO Forum, 2008.

[45] Dill, D. D., "Higher education markets and public policy. Higher education policy", Vol. 10, No. 3-4, pp. 167-185, 1997.

[46] Zemsky, R., "Making Reform Work: the Case for Transforming American Higher Education". Rutgers University Press, 2009.

[47] Bok, D., "Universities in the Marketplace: The Commercialization of Higher Education", Princeton, NJ: Princeton University Press, 2003. 